\title{
Discussion About The Impact of College Chinese on Promoting College Students to Open Up Their Business Or Find a Job
}

\author{
Ma Chunna \\ Tourism College Of Chang Chun University, China \\ 82354823@163.com
}

Keywords: Graduates, Employment Power, Innovation Ability, Chinese Education

\begin{abstract}
In the intense competition of employment, the graduates of colleges want to obtain the corresponding job opportunities, they must have sufficient abilities of employment power and innovation abilities. To this end, Chinese education of colleges should play an important role in improving employment ability and the innovation ability of college students. This paper analyzes and discusses the effect of Chinese education of colleges on the improvement of College Students' employment ability and the ability to start a business.
\end{abstract}

\section{The Standards of Choosing the Talents among the Graduates for the Employers}

In the times of economic globalization, the competition among enterprises is the competition of talents. Therefore, the conditions of the enterprises' talent selection are more stricter than before, the requirements are also getting higher and higher. Many enterprises require the graduates should have not only corresponding professional bases and related skills, but also good sense of morality, personality and other good character. Through the investigation and summarization of the realities, we find that many enterprises choosing the graduates will focus on the quality such as their integrity, development potential, learning ability, team spirit, innovative spirit and ability to adapt. The change, as it is, is great, compared with the traditional way focus on the graduates' marks and awards have obtained.

The employers consider so many factors in order to ensure that the graduates can play a remarkable role in their posts, at the same time can be able to have personal accomplishment and team spirit, also have corresponding innovative consciousness and innovative ability accordingly. This is not only good for enterprise development and enterprise culture, but also benefit for personal growth and future development of the graduates in their career. These requirements of enterprises when choosing the talents have the positive effects on the colleges and universities begin to put emphasis on the all-round development of the students, not just teach the students the professional knowledge by the traditional ways. Chinese education of Colleges should be make universal, and play an important role in cultivating the character and abilities of college students in employment.

\section{The Role of College Chinese in the Cultivation of College Students' Employment Ability and Innovation Ability}

College Chinese is a course that can be popularized in the higher education school based on the cultivation of students' Chinese accomplishment and the improvement of College Students' language ability. It plays an important role in promoting the all-round development of college students, and cultivating the talents of the social needs.

The most basic effect of College Chinese course is to improve and strengthen the students' ability of listening, speaking, reading and writing continuously. They are not only the basic language literacy college students should master, but also the ability of language the students should improve continuously. "Listening" means someone should understand others' presentation, and can imagine or association. "Speaking " is to express clear and appropriate to make other people 
understanding what you want to say. The ability of reading is to understand the text content, and can master the key. " Writing" refers to the ability to express their needs and feelings with reasonable text content. Through listening, speaking, reading and writing, people can communicate with other people, express their own thinking and understand others' ideas.

Listening, speaking, reading and writing ability has an important influence on College Students' life, no matter study or employment. First of all, listening, speaking, reading and writing skills can help students to communicate effectively with others, also to deepen their understanding and caring[1]. Secondly, listening, speaking, reading and writing ability has an important role in the study of other courses for college students. College Students' professional courses and other courses of study need to have a good understanding ability and expression ability. This is help for their ability to understand and master the contents in the study. Finally, only when college students have the ability to read and write, can understand the requirements and ideas of the employers in the work, and show their thinking and application result about one project to the investors for the students who want to start up their own work team or company. And many jobs also require college students to analyze or write related text materials.

Besides helping students grasp the basic ability of listening, speaking, reading, and writing, College Chinese can encourage students to improve language skills. Language skill can modify the expression and abstract of speech. It can make students to express clear and reasonable, also benefit for other people to understand, make communication to achieve good results. Good verbal skills for the students have a available role, which is mainly reflected in the aspects of communication. First of all, when the graduates have the interviews with HR, excellent verbal skills can help the students to express their views and opinions clearly and appropriately. That can let the interviewer know the talents and advantages they have immediately, so as to get the offers. Secondly, excellent verbal skills enable the students to communicate with the customers, colleagues and leadership effectively. This is very important for communicating with colleagues, reporting on the efforts to leaders, also for promoting the good cooperation with customers.

Reading and writing Chinese is a creative intelligence activity. Creativity is the essence of reading, and also the ultimate target of reading. Read and write, is to create, create means be free from the thinking of books themselves, and present a different idea from the book. However, because of college Chinese has been ignored for a long time, teachers do not teach seriously, students are not interested in learning. Teachers ignore the open meanings of the articles and students' individual differences. There are standardized interpretations of the contents that hinder the enthusiasm and initiative of the students to explore and create as time passes. Therefore, it is important that Chinese education in the colleges and universities should be made universal and be reformed so as to stimulate creative reading and writing consciousness of students, cultivate students' innovation consciousness and creative ability.

Humanistic qualities represent the mastery and research skills of humanities knowledge, and the formation of internal self-cultivation. The humanistic quality of college students not only has an impact on their own values and moral consciousness, but also has a certain guiding role in the behavior method. With rich cultural heritage and cultural knowledge of College Chinese, students can be influenced in the learning process, and gradually formed a more excellent accomplishment gradually.

College Students' humanistic literacy level has a certain effect on employment. Good humanistic quality can make students exhibit good behavior habits and personal character, also can make them behave decently at work. At the same time, students with good humanistic quality will show their passions on the work, and do something seriously, express their reasonable views, accept the advices from others humbly. In addition, the humanistic quality of the students can be show through the corresponding behavior, which is a microcosm of the individual comprehensive quality.

\section{The Role of College Chinese in the training of Students' Employment Ability}

In order to promote college students to obtain advantage in employment, College Chinese must play an important role in college students' employment ability and strength training. Listening, 
speaking, reading and writing ability has an important influence on College Students' employment. First of all, college students should continue to consolidate their listening and speaking ability to read and write in the study of College Chinese[2]. Secondly, College Chinese teaching should focus on improving the expression skills of College students. Students should use the appropriate learning and other activities to improve their verbal skills. In addition, students should continue to strengthen their writing ability, master the writing skills in the study of Chinese, and improve their writing ability by imitating and training gradually.

The humanistic quality of college students is an effective representation of their comprehensive quality. The cultivation of students' humanistic quality should be done through teaching read. College Chinese teaching should provide students with adequate reading materials, and make it form the ability and habits of reading, so as to make students to expand their views, master reading information in the reading activities continuously, improve the ability of reading and understanding. In a certain extent, that can promote thinking ability and creative ability. At the same time, students should use reading skills to expand their reading field and reading quantity in order to improve their reading ability and humanistic quality[3].

College students can get relevant skills and knowledge by learning college Chinese, improve their ability certainly, but just studying college Chinese course is not enough. They need to do some appropriate practical activities to improve and exercise. First of all, students can take part in the activities organized by campus leagues and social practice, so that students can exercise of their ability to use their language. They also can participate in campus speech contests and other activities like social practice and investigation, reading and writing the reports and essay to improve their writing and speaking skills.

\section{Summary}

College Students'employment situation is not optimistic. College Chinese education should pay more attention to training college students' employment power and innovation ability for the graduates who want to get good jobs or start up. College Chinese is not only to improve the basic ability of college students, but also to cultivate students' comprehensive abilities in other aspects such as writing ability, language expression ability and humanistic quality.

\section{References}

[1] Li Haiping, Discussion on the Effects and Strategies of Chinese Abilities for College Students' Employment, College Education, 12(2013):150-152

[2] Chen Qing, Discussion on the Effects of College Chinese's New System for the Talents, Reporter of Xinxiang College, 4(2014): 143-144

[3] Xie Wenxin, The Improvement of Employment through Cultivating Chinese Literacy,The Road of Success, 1(2012):119-120 